\title{
Activation of plasmacytoid dendritic cells promotes AML-cell fratricide
}

\author{
Kavin Fatehchand ${ }^{1,2}$, Payal Mehta ${ }^{2}$, Christopher B. Colvin², Nathaniel J. \\ Buteyn 2,4, Ramasamy Santhanam², Giovanna Merchand-Reyes ${ }^{2,4}$, Hafza Inshaar ${ }^{2}$, \\ Brenda Shen ${ }^{2}$, Xiaokui Mo $^{3}$, Bethany Mundy-Bosse ${ }^{2}$, Susheela Tridandapani ${ }^{1,2}$ and \\ Jonathan P. Butchar ${ }^{2}$ \\ ${ }^{1}$ Medical Scientist Training Program, Wexner Medical Center, The Ohio State University, Columbus, OH 43210, USA \\ ${ }^{2}$ Department of Internal Medicine, Wexner Medical Center, The Ohio State University, Columbus, OH 43210, USA \\ ${ }^{3}$ Center for Biostatistics, Department of Biomedical Informatics, The Ohio State University, Columbus, OH 43210, USA \\ ${ }^{4}$ Molecular, Cellular and Developmental Biology Program, The Ohio State University, Columbus, OH 43210, USA \\ Correspondence to: Jonathan P. Butchar, email: butchar.2@osu.edu \\ Susheela Tridandapani, email: tridandapani.2@osu.edu
}

Keywords: plasmacytoid dendritic cells; interferon-beta; acute myeloid leukemia; fratricide

Abbreviations: PDC: plasmacytoid dendritic cell; AML: acute myeloid leukemia; IFNß: Interferon-beta

Received: January 07, $2021 \quad$ Accepted: April 06, $2021 \quad$ Published: April 27, 2021

Copyright: (C) 2021 Fatehchand et al. This is an open access article distributed under the terms of the Creative Commons Attribution License (CC BY 3.0), which permits unrestricted use, distribution, and reproduction in any medium, provided the original author and source are credited.

\section{ABSTRACT}

Acute myeloid leukemia (AML) is characterized by the proliferation of immature myeloid blasts and a suppressed immune state. Interferons have been previously shown to aid in the clearance of AML cells. Type I interferons are produced primarily by plasmacytoid dendritic cells (PDCs). However, these cells exist in a quiescent state in AML. Because pDCs express TLR 7-9, we hypothesized that the TLR7/8 agonist $\mathbf{R} 848$ would be able to reprogram them toward a more active, IFN-producing phenotype. Consistent with this notion, we found that R848-treated pDCs from patients produced significantly elevated levels of IFN $\beta$. In addition, they showed increased expression of the immune-stimulatory receptor CD40. We next tested whether IFN $\beta$ would influence antibody-mediated fratricide among AML cells, as our recent work showed that AML cells could undergo cell-to cell killing in the presence of the CD38 antibody daratumumab. We found that IFN $\beta$ treatment led to a significant, IRF9dependent increase in CD38 expression and a subsequent increase in daratumumabmediated cytotoxicity and decreased colony formation. These findings suggest that the tolerogenic phenotype of pDCs in AML can be reversed, and also demonstrate a possible means of enhancing endogenous Type I IFN production that would promote daratumumab-mediated clearance of AML cells.

\section{INTRODUCTION}

Acute Myeloid Leukemia (AML) is associated with defective innate and adaptive immune responses, as is seen with other malignancies. This stems from both direct and indirect interactions with leukemia stem cells (LSCs), regulatory $T$-cells, tolerogenic myeloid stem cells or tolerogenic dendritic cells [1]. Despite this immune suppression, antibody-based immune therapies for AML are being actively explored, either as single agents or in combination with other therapies [2]. In a recent study we demonstrated that daratumumab, a CD38 antibody was able to effectively mediate AML cell-to-cell killing, or fratricide [3]. However, the effect of daratumumab depended on the co-administration of IFN $\gamma$ to enhance the expression of CD38 and the high affinity IgG receptor CD64/Fc $\gamma$ RI. Type I and Type II interferons have previously been tested in clinical trials for AML. Results from a trial with IFN $\gamma$ showed that it was toxic at dosages equivalent to those needed to induce differentiation of AML cells in vitro [4]. Interferon- $\alpha(\operatorname{IFN} \alpha)$ has been tested as a maintenance therapy, showing lower toxicity than IFN $\gamma$ but not conferring 
any benefit against AML [5, 6]. However, Type I interferons have not been examined as a dual-treatment with anti-CD38 within the context of AML. Type I and Type II interferons signal through distinct pathways but there is also sufficient overlap (e.g., STAT1 phosphorylation) [7] to suggest that they may be of benefit when combined with daratumumab, and with fewer potential toxicities. Among the Type I interferons, IFN $\beta$ shows the strongest receptor binding and elicits the most downstream intracellular activity [8].

Plasmacytoid dendritic cells (pDC) are major contributors to Type I IFN responses $[9,10]$ and also play an important role in bridging innate and adaptive immunity [9]. pDCs express TLR 7-9 and are able to produce many cytokines including TNF- $\alpha$, CXCL8, and IL-6, but most importantly Type I Interferons after TLR stimulation [1115]. Within the context of cancer, $\mathrm{pDCs}$ have been shown to take on a more tolerogenic state resulting in the induction of regulatory $T$-cells and production of lower amounts of Type I Interferon which is required for tumor clearance [16].

In AML, it has been shown that both FLT3-ITD ${ }^{+}$and FLT3-ITD ${ }^{-}$patients have higher frequencies of circulating pDCs compared to healthy donors. However, these pDCs express lower levels of HLA-DR, which may explain their inability to present antigen as effectively as healthy-donor cells [17]. Nevertheless, since pDCs express Toll-like receptors (TLR) 7-9 [12, 18], activating them with TLR agonists may facilitate a reprogramming toward a more active phenotype [16].

Here, we examined the effects of the TLR7/8 agonist R848 on the phenotype and cytokine production of AML-patient pDCs. In agreement with previous studies [19] we found that R848 led to higher expression of CD40. Notably, it also increased IFN $\beta$ production by AMLpatient pDCs, and this induced an upregulation of CD38 in AML cells. Consequently, IFN $\beta$ combined with the anti-CD38 antibody daratumumab, led to fratricide of the AML cells. Taken together, these results demonstrate that targeting pDCs therapeutically may be an effective means of clearing AML, and this could be particularly useful in patients unable to undergo chemotherapy.

\section{RESULTS}

\section{TLR 7/8 agonists reverse the tolerogenic phenotype of AML-patient pDCs}

Relative to healthy donors, AML patients have elevated frequencies of pDCs, but these cells show decreased expression of activation markers [17]. In order to test whether the TLR7/8 agonist R848 could reverse this, we began by first identifying pDCs from AML patients and from healthy donor PBMCs ( $\mathrm{Lin}^{-} / \mathrm{HLA}-\mathrm{DR}^{+} / \mathrm{CD} 123^{+} /$ $\mathrm{BDCA}^{+}$, Figure 1A). Next, we measured surface expression of the $\mathrm{pDC}$ activation marker $\mathrm{CD} 40$ and the transmigration marker CD62L, as well as of CD80 and CD86. As shown in Figure 1B, pDCs isolated from AML patients trended toward reduced $\mathrm{CD} 40(p=0.07)$, and $\mathrm{CD} 62 \mathrm{~L}$ was significantly lower $(p=0.02)$. CD80 and CD86 showed no differences. We next tested whether we could shift the phenotype of pDCs into a more active state. Because pDCs express TLR7-9 $[12,18]$ we treated PBMCs from healthy donors and from AML patients with the TLR 7/8 agonist R848. Following this we measured surface expression of CD40, CD62L, CD80 and CD86 on the pDCs. As shown in Figure $1 \mathrm{C}$, healthy-donor pDCs responded to $1 \mu \mathrm{M}$ of $\mathrm{R} 848$ within 24 hours (Figure 1C), with significant upregulation of costimulatory markers CD40, CD80 and CD86. This is in agreement with results from Gibson et al. [20]. The migration marker CD62L was also significantly upregulated (Figure 1C). However, AML-patient pDCs showed a more muted response. There was no increase in CD86, CD80 or CD62L. Rather, only CD40 showed an upregulation, and only after 48 hours of incubation with $5 \mu \mathrm{M}$ R848 (Figure 1D). This exemplifies the resistance of patient pDCs to immune-activating stimuli relative to their healthy-donor counterparts. The upregulation of CD40, however, suggests that they are at least partially responsive to TLR7/8 agonists as CD40 is a driver of activation and maturation [21].

\section{R848 induces functional changes in AML-patient pDCs}

It has been shown that TLR7 agonist treatment can induce pDCs to produce Type I IFNs [22, 23], which drives antitumor effects. Along with this they may effect cytotoxicity via TRAIL $[22,23]$. To confirm the ability of the TLR7/8 agonist R848 to similarly activate pDCs, we FACS-sorted AML-patient pDCs and treated them for 48 hours with or without R848. IFN $\beta$ and TRAIL were measured by ELISA and qPCR, respectively. Results showed that R848-treated pDCs expressed significantly higher levels of IFN $\beta$ (Figure 2A, $n=4$ donors). TRAIL expression was substantially elevated, but the difference was not statistically significant with a two-tailed $t$-test (Figure 2B, $n=7$ donors, $p=0.0917$ ).

Although TRAIL has previously been shown to be induced in pDCs [22, 23], the stronger effect of R848 on IFN $\beta$ as well as the known insensitivity of AML cells to TRAIL-mediated killing [24-26] led us to focus on IFN $\beta$. In particular, we investigated whether pDC-derived IFN $\beta$ may lead to upregulation of a targetable antigen on AML cells. We had previously shown that the Type II interferon IFN $\gamma$ led to strong upregulation of CD38 on AML cells, which subsequently facilitated cytotoxicity of AML cells amongst themselves upon addition of the anti-CD38 antibody daratumumab [3]. Hence, we sought to determine whether IFN $\beta$ acted in a similar manner, up-regulating CD38 on AML cells. For this, primary AML apheresis samples were treated for 24 hours with or without IFN $\beta$ and surface expression of CD38 was measured by flow cytometry. Results showed that IFN $\beta$ significantly increased the expression of $\mathrm{CD} 38$ (Figure $2 \mathrm{C}, n=8$ donors). 


\section{IFN $\beta$-mediated up-regulation of CD38 requires canonical and non-canonical pathways}

We have previously shown that Type II IFN upregulated CD38 on AML cells through p38, NF- $\kappa B$, and JAK/STAT [3]. Type I and Type II IFN pathways differ in some downstream signaling components [27], so we sought to determine the mechanism by which IFN $\beta$ upregulated CD38. In the canonical pathway, Type 1 IFNs bind to the IFNAR receptor, which consists of the IFNAR1 and IFNAR2 subunits. IFNAR1 associates with the Jakfamily kinase Tyk2, while IFNAR2 associates with Jak1.
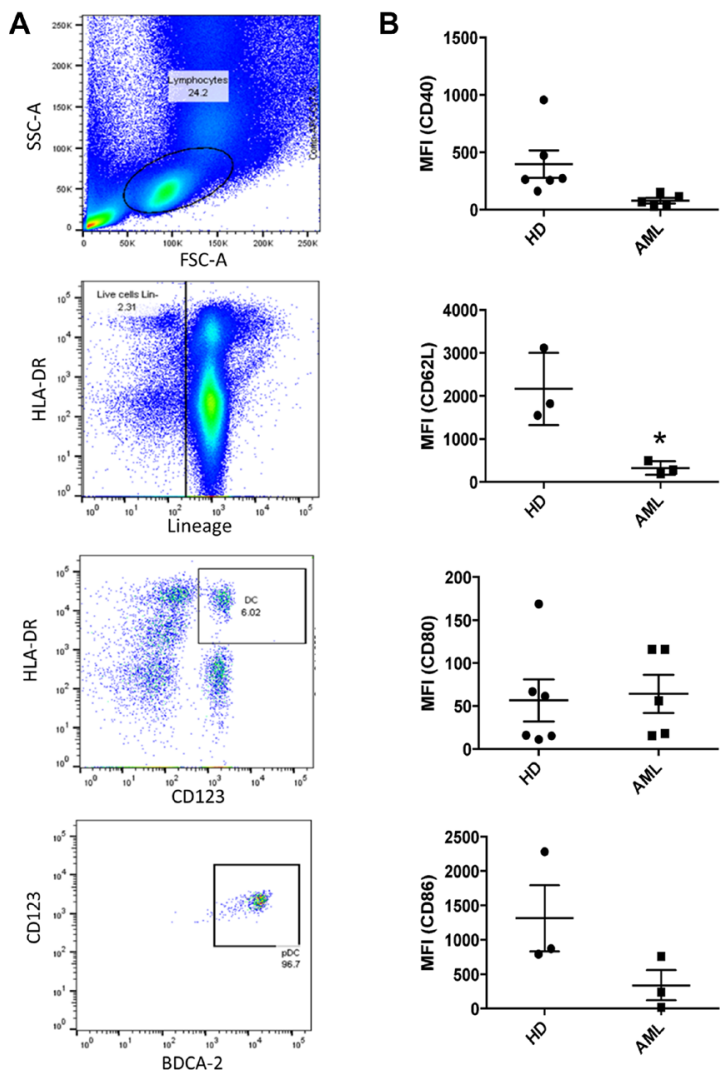
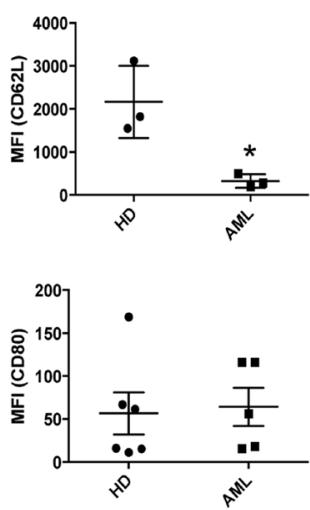

C
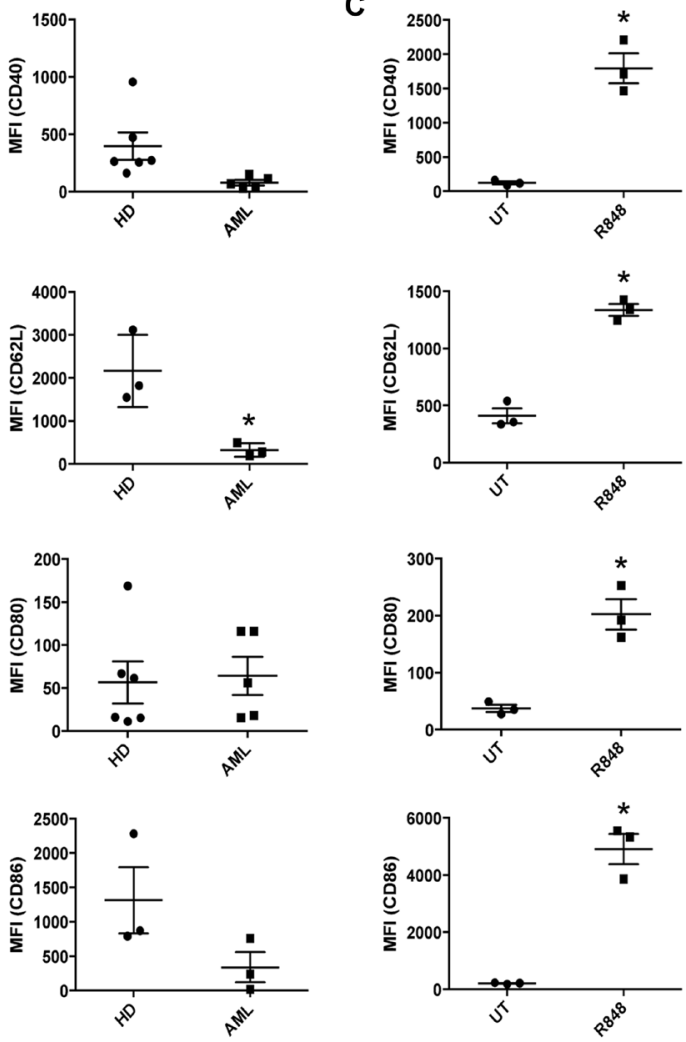

D
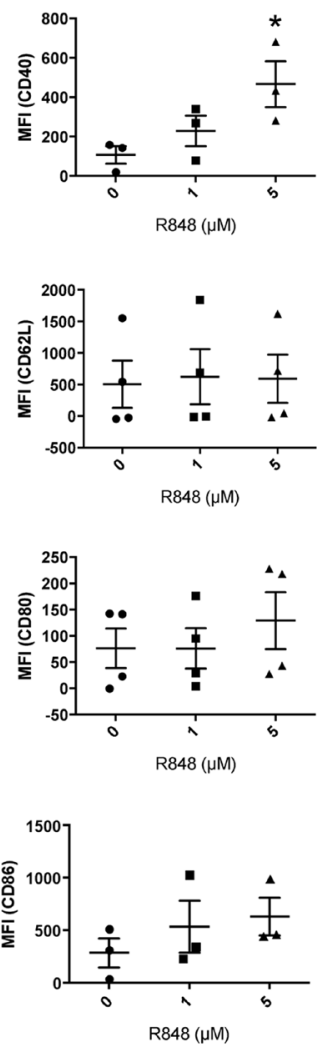

Figure 1: TLR7/8 agonists reverse the tolerogenic phenotype of AML-patient pDCs. (A) Identification of pDCs by flow cytometry, gating on scatter, lineage, HLA-DR, CD123 and BDCA2. Exclusion (not shown) was done based on CD3, CD14, CD16, CD19, $\mathrm{CD} 20$ and CD56. pDCs were identified as HLA-DR ${ }^{+} / \mathrm{CD} 123^{+}$followed by $\mathrm{BDCA} 2^{+} / \mathrm{CD} 123^{+}$. (B) Healthy-donor $(n \geq 3$ donors) and AMLpatient ( $n \geq 3$ donors) PBMC were stained in order to identify pDC populations by cytometry described above. Surface expression of CD40, CD62L, CD80 and CD86 on pDCs were measured by flow cytometry. Mean fluorescence intensity (MFI) is plotted. (C) Healthy-donor ( $n=3$ donors) PBMC were treated with the TLR7/8 agonist R848 $(1 \mu \mathrm{M})$ for 24 hours. pDC populations were identified as described above and surface expression of CD40, CD62L, CD80 and CD86 was measured. (D) AML-patient ( $n \geq 3$ donors) PBMC were treated with 0,1 or $5 \mu \mathrm{M}$ R848 for 48 hours. CD40, CD62L, CD80 and CD86 expression was measured in pDCs as above. ${ }^{*} p \leq 0.05$.
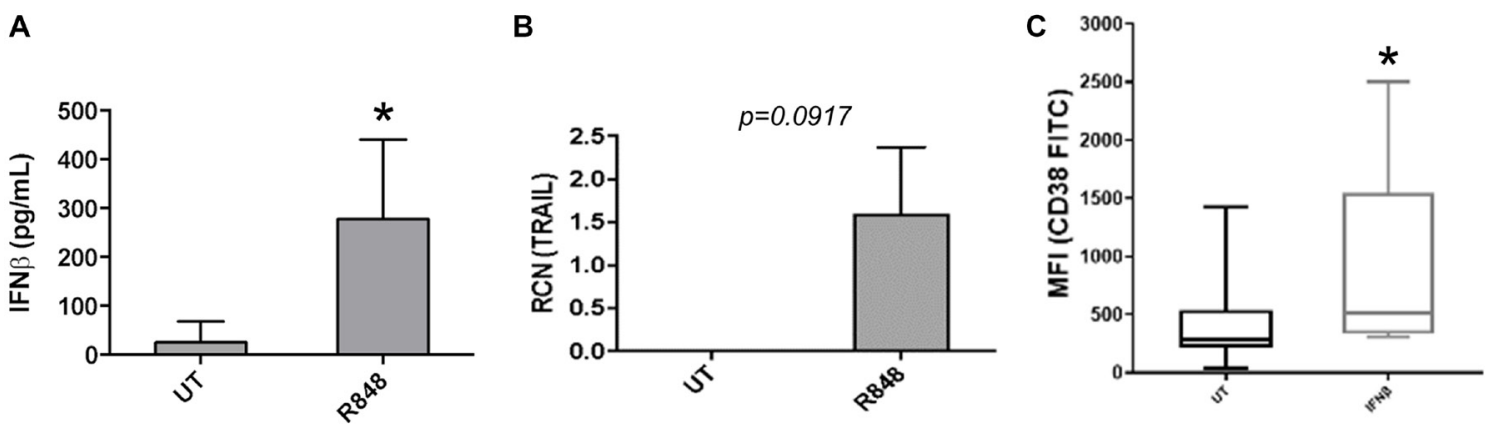

Figure 2: R848 induces functional changes in AML-patient pDCs. (A and B) pDCs were sorted from AML-patient PBMC samples, then treated with or without R848 $(5 \mu \mathrm{M})$ for 24 hours. ELISAs were done to measure IFN $\beta$ ( $n=4$ donors) (A) and qPCR was done to measure TRAIL ( $n=7$ donors). (B and C) Primary AML apheresis samples ( $n=8$ donors) were treated with or without IFN $\beta$ (500 $\mathrm{U} / \mathrm{mL}$ ) and surface expression of CD38 was measured by flow cytometry. Mean fluorescence intensity is plotted. ${ }^{*} p \leq 0.05$. 
Ligand binding leads to phosphorylation of Jak1 and Tyk2. Following this, STAT1 and STAT2 are phosphorylated, leading to their activation. This results in the formation of the IFN-stimulated gene factor 3 (ISGF3) complex as IRF9 is recruited to the phosphorylated STAT1/STAT2 dimer. This then induces expression of Interferon Stimulated Genes (ISGs) [27]. In the non-canonical pathway, Type 1 Interferons can act independently of STAT signaling, through both the PI3K and MAPK pathways [28]. Erk can also play a role apart from ISGF3, associating with STAT1 following IFN $\beta$ treatment [29].

To determine which of these were required for IFN $\beta$ mediated up-regulation of CD38 expression, primary AML apheresis samples were pre-treated with inhibitors for Jak 1/2 (Ruxolitinib, targeting the JAK/STAT canonical pathway), p38 (SB202190, targeting the non-canonical p38 MAPK pathway) and MEK (PD0325901, targeting Erk). Western blots were done to verify the efficacy of the Jak 1/2 inhibitor (Figure 3A, left panel), the p38 inhibitor (Figure 3B, left panel) and Erk inhibitor (Figure 3C, left panel). qPCR results showed that upregulation of CD38 by IFN $\beta$ was significantly dampened by the inhibition of both Jak $1 / 2$ and p38 (Figure 3A and 3B, right panels). MEK/ ERK did not seem to be required for this IFN $\beta$-mediated up-regulation of CD38 (Figure 3C, right panel). As shown in the blot (Figure 3C, left upper panel), we observed strong basal Erk phosphorylation. This is frequently seen in AML samples, both cell-line and primary [30-32]. However, the efficacy of PD0325901 was seen, as it substantially reduced Erk phosphorylation.

These results indicate that both the canonical and non-canonical pathways play a role in IFN $\beta$-mediated upregulation of CD38 in AML cells. It should be noted that the $\mathrm{IC}_{50}$ of Ruxolitinib for Tyk2 is approximately fourfold of what was used here $(19 \mathrm{nM} \pm 3.2$ [33] versus our use of $5 \mathrm{nM}$ ). Tyk2 has been shown to drive activation of Vav [34], which leads to Rac1 activation and this is required for IFN-mediated activation of p38 (reviewed in [27, 35]). It has also been shown that inhibition of $\mathrm{p} 38$ does not interfere with STAT1/STAT2 phosphorylation, nor formation of the canonical ISGF3 complex consisting of STAT1, STAT2 and IRF9 [36].

\section{pDC-dependent IFN $\beta$ production enhances CD38 expression on AML cells}

Having determined the molecular mechanism by which recombinant IFN $\beta$ treatment results in enhanced CD38 expression on AML cells, we next asked whether pDC-dependent IFN $\beta$ production after R848 treatment could enhance CD38 expression on AML cells in a paracrine fashion. For this, we collected pDC-positive and $\mathrm{pDC}$-negative fractions by flow-cytometry sorting of primary AML PBMC samples. The two sets of primary AML cells, pDC-positive and pDC-negative, were then treated with R848 $(5 \mu \mathrm{M})$ overnight. Cell supernatants from both sets were collected and placed on MV4-11 cells in the presence or absence of a neutralizing antibody against IFN $\beta$ for 24 hours. A schematic for this primarycell treatment and subsequent conditioned-media assay is shown in Figure 4A. Supernatants from the primary cells treated with R848 were collected to measure IFN $\beta$ by ELISA (Figure 4B, $n=5$ donors). Results showed that R848 enhanced IFN $\beta$ production in the $\mathrm{pDC}$-positive but not pDC-negative samples (Figure 4B), suggesting that this IFN $\beta$ response was more rapid than the required 48 hours for CD40 upregulation as in Figure 1. As expected, this increased IFN $\beta$ was offset by IFN $\beta$-neutralizing antibody (Figure 4B). Conditioned media from these primary-cell cultures was then placed onto MV4-11 cells for 24 hours. Following this, CD38 expression on the MV4-11 cells was measured using flow cytometry. Results showed that CD38 expression was upregulated in MV411 cells that had been incubated with the conditioned media from pDC-positive cultures that had been treated with R848. This was significantly attenuated by IFN $\beta-$ neutralizing antibody (Figure 4C and 4D). In MV4-11 cells treated with conditioned media from $\mathrm{pDC}$-negative cells, there was no upregulation of $\mathrm{CD} 38$, even if the conditioned media contained R848. Hence, there was no direct effect on AML cells from R848 in the conditioned media with respect to CD38 expression. These results suggest that R848 elicits IFN $\beta$ from $\mathrm{pDCs}$, and that this IFN $\beta$ is biologically active and leads to the upregulation of CD38 on AML cells.

\section{IFN $\beta$-induced AML-cell cytotoxicity is enhanced with anti-CD38 antibody daratumumab}

We next examined whether IFN $\beta$ could induce functional changes in AML cells, such as those seen earlier with IFN $\gamma$ [3]. We treated two AML cell lines (OCI-AML3 and MV4-11) and primary AML apheresis samples with $\operatorname{IFN} \beta(500 \mathrm{U} / \mathrm{mL})$ for 24 hours and tested their ability to phagocytose antibody-opsonized target cells, here opsonized sheep red blood cells. As shown in Figure 5A$5 \mathrm{C}$, IFN $\beta$ treatment significantly enhanced the phagocytic capacity of both cell lines (Figure 5A and 5B) and primary AML cells (Figure 5C).

We next tested the ability of IFN $\beta$ to promote antibody-mediated fratricide among AML cells. Here, we treated the AML cell line OCI-AML3 with or without IFN $\beta$ $(500 \mathrm{U} / \mathrm{mL})$ in the presence or absence of the anti-CD38 antibody daratumumab $(20 \mu \mathrm{g} / \mathrm{mL})$ for 48 hours. Cell death was measured via lactate dehydrogenase (LDH) release. Results indicated that IFN $\beta$ alone significantly increased cytotoxicity (Figure 5D), which was in line with our previous findings with IFN $\gamma$ [3]. Notably, the combination of IFN $\beta$ and daratumumab led to significantly higher cytotoxicity than IFN $\beta$ alone (Figure 5D). Because this assay was done using conditioned media and an AML cell line rather than primary samples containing multiple cell 
types, these results suggest that daratumumab may have promoted cell-against-cell fratricide. We have observed such fratricide in an earlier study using daratumumab [3].

In order to corroborate these findings, we treated the AML cell line MV4-11 with or without IFN $\beta$ (500 U/ $\mathrm{mL}$ ) in the presence or absence of daratumumab for 48 hours. We then performed a 10-day colony-forming assay, scoring colony-forming units in a double-blinded fashion.
Results showed that IFN $\beta$ trended toward a reduced number of colonies $(p=0.09)$, but the combination of IFN $\beta$ plus daratumumab led to significantly fewer colonies than IFN $\beta$ alone (Figure 5E and 5F). Taken together, these results suggest that activation of TLR7/8 on pDCs induces the production of IFN $\beta$, which then provides an opportunity for daratumumab-mediated AMLcell fratricide.

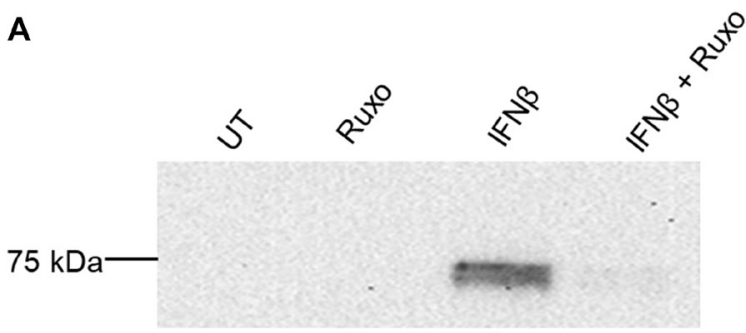

IB: pSTAT1

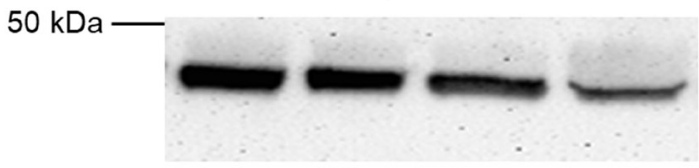

IB: Calreticulin

B

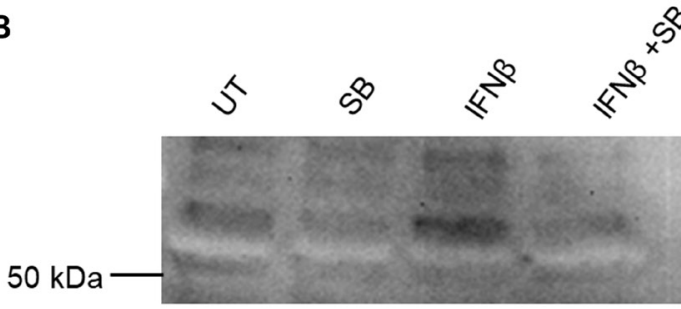

IB: p-MAPKAPK-2

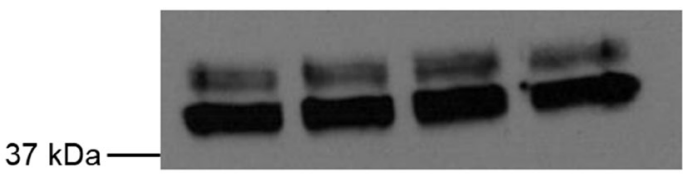

IB: Total MAPKAPK-2

C

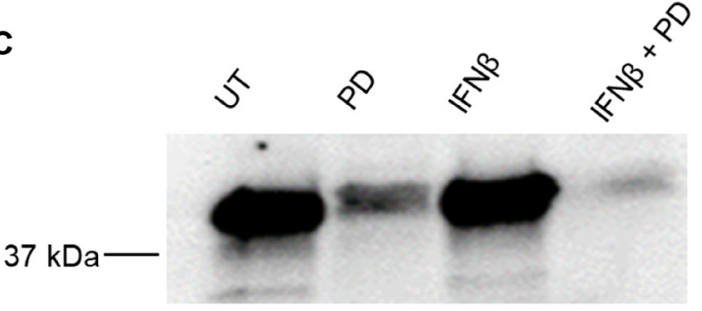

IB: $p-E R K$

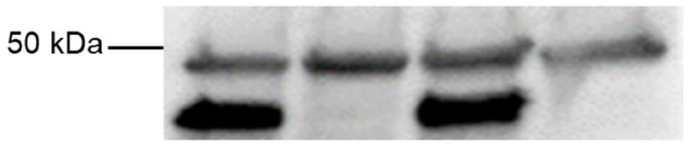

IB: Calreticulin
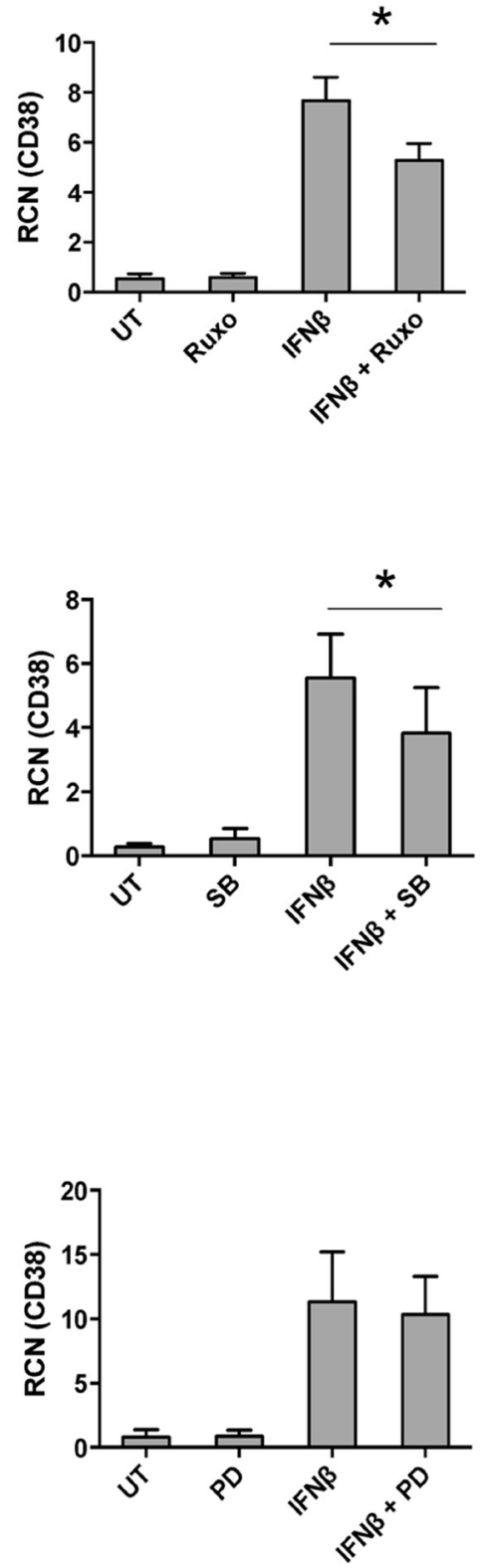

Figure 3: IFN $\beta$-mediated up-regulation of CD38 requires canonical and non-canonical pathways. (A-C) Primary AML apheresis samples were pre-treated for 30 minutes with either the JAK 1/2 inhibitor Ruxolitinib (Ruxo, $5 \mathrm{nM}, n=4$ donors) (A), the p38 inhibitor SB202190 (SB, $1 \mu \mathrm{M}, n=6$ donors) (B) or the Mek inhibitor PD0325901 (PD, $0.5 \mu \mathrm{M}, n=5$ donors) (C) and then treated for 24 hours with or without IFN $\beta(500 \mathrm{U} / \mathrm{mL})$. For each respective set, qPCR was done to measure CD38 (A-C, right-hand panels). Left-hand panels show representative blots verifying the efficacy of the inhibitors. ${ }^{*} p \leq 0.05$. 


\section{DISCUSSION}

pDCs have been shown to be the major cell type for Type I interferon production ([20,37] and reviewed in [38] and [39]). Here, we have shown that activation of AMLpatient pDCs through TLR 7/8 agonist treatment ultimately leads to AML-cell destruction by IFN $\beta$ and daratumumab. Combined IFN $\beta$ and daratumumab led to significantly greater cell death than IFN $\beta$ alone, suggesting that daratumumab may have promoted AML-cell fratricide. We have observed this phenomenon previously in a study of Type II interferon [3]. R848-treated pDCs showed higher expression of CD40, and produced IFN $\beta$. IFN $\beta$ treatment of AML cells led to increased expression of CD38, and conferred the ability to target one another for fratricide. In our working model (Figure 5G), we propose that R848 can activate $\mathrm{pDCs}$ such that they produce IFN $\beta$, which in turn increases expression of the daratumumab target CD38 on AML cells. This leads to antibody-mediated AML-cell fratricide.

A

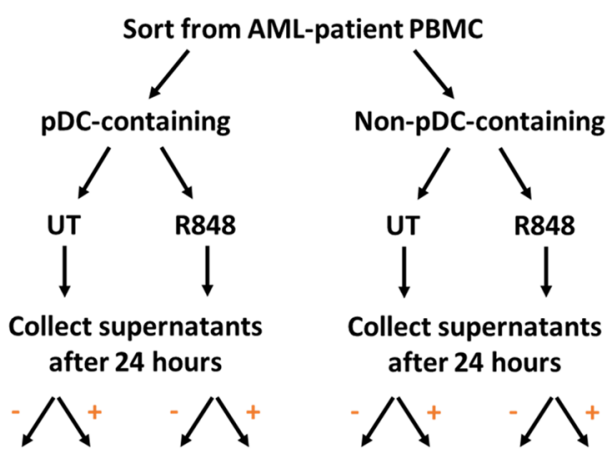

Place conditioned media on MV4-11 cells for 24 hours

Measure CD38 expression via flow cytometry

B

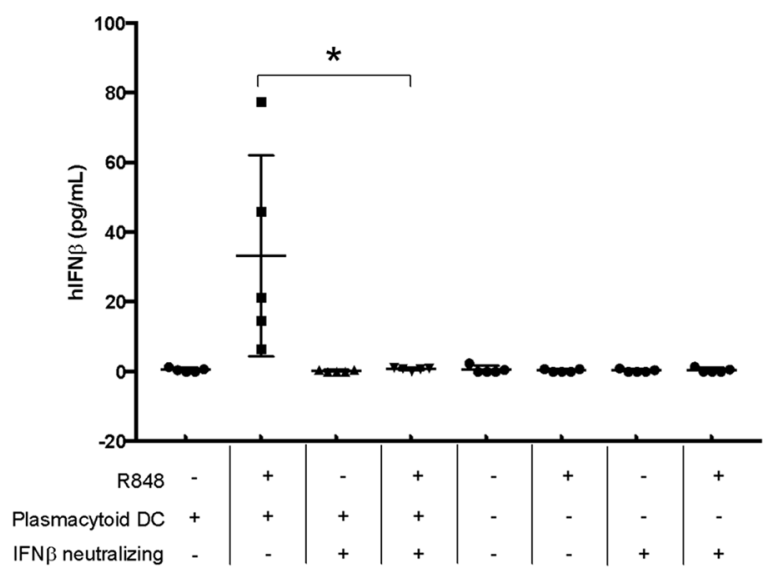

By examining the activation and costimulatory markers CD40, CD80 and CD86 as well as the migration marker CD62L, we were able to show that the AML-patient pDCs express less CD62L (Figure 1B) and that they are less responsive in general to R848 than healthy-donor $\mathrm{pDCs}$ (Figure 1D versus Figure 1C). The responses to R848 seen with the healthy-donor cells are in agreement with Gibson et al., 2002 [20]. Even though R848 did not activate patientderived $\mathrm{pDCs}$ to the same degree, it did lead to upregulation of CD40 and production of IFN $\beta$. This is important, as CD40 activity drives activation and maturation [21] and its expression is often reduced in tumor-associated dendritic cells [40]. It also suggests that these cells retain the ability to be at least partially responsive to immune modulators such as TLR7/8 agonists. CD62L, a marker of motility [41], is strongly expressed on pDCs [42] yet reduced in pDCs within the context of cancers such as non-Hodgkin's lymphoma [43]. Our findings are in agreement, such that pDCs from AML patients express significantly less CD62L than those from healthy donors.
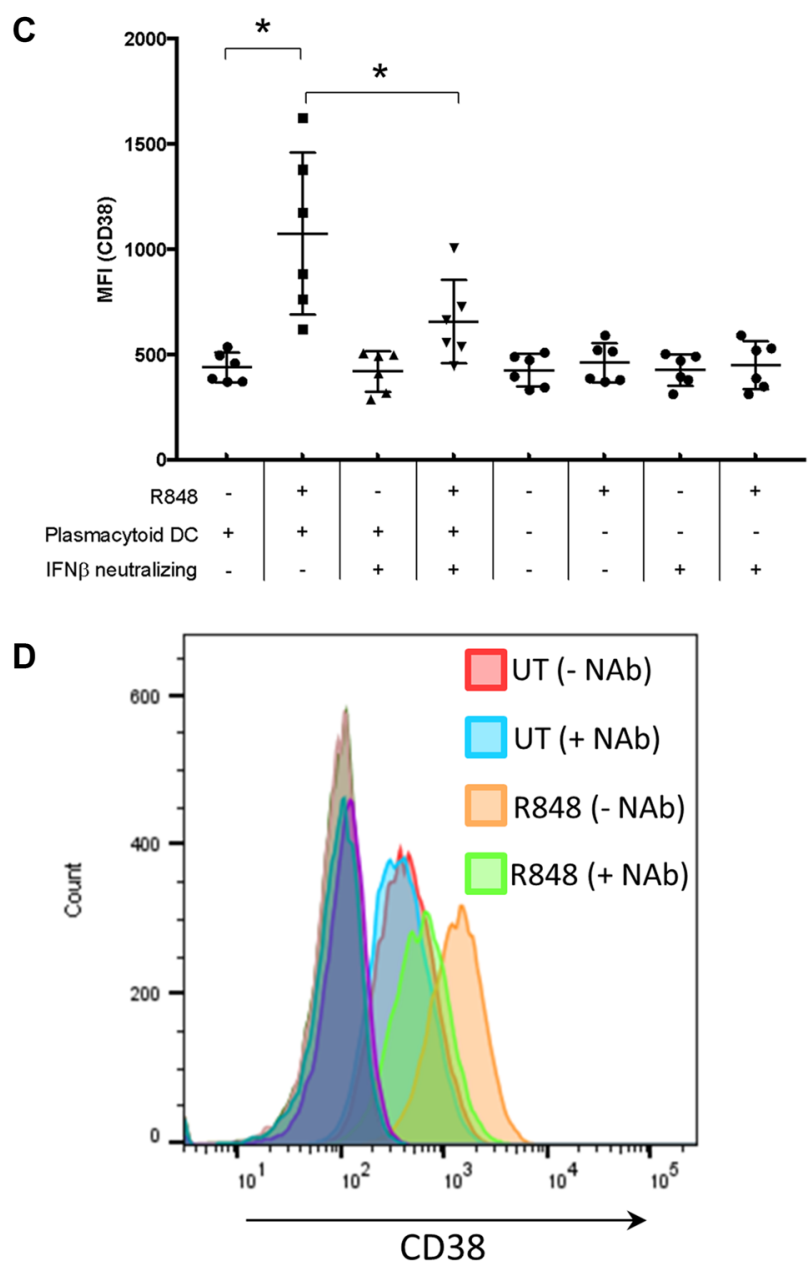

Figure 4: pDC-dependent IFN $\beta$ production enhances CD38 expression on AML cells. (A) Schematic of experimental procedure. AML PBMC samples $(n=5)$ were sorted for both $\mathrm{pDC}^{+}$and $\mathrm{pDC}^{-}$populations, then treated overnight with or without $\mathrm{R} 848(5$ $\mu \mathrm{M})$. Supernatants were collected and placed on MV4-11 cells in the presence or absence of IFN $\beta$-neutralizing antibody (1000 U/mL) for 24 hours. (B) Supernatants were collected and IFN $\beta$ measured by ELISA. (C) Cells were stained for CD38 and surface expression measured by flow cytometry. (D) Representative histogram from (C). ${ }^{*} p \leq 0.05$. 
pDCs can contribute to tumor clearance by inducing TRAIL-mediated apoptosis or by the production of Type 1 Interferons [23, 44]. R848 did induce some TRAIL expression on pDCs from the AML-patient samples we tested ( $p=0.09)$, but AML cells are relatively insensitive to TRAIL. This phenomenon has previously been reported but certain agents have been shown to sensitize AML cells to TRAIL-dependent killing. For example, triptolide is able to sensitize AML cells to TRAIL-mediated apoptosis by decreasing XIAP expression and increasing DR5 expression on AML cells [25]. However, due to its severe toxicity and water-insolubility, the clinical use of this drug is quite limited [45]. Nonetheless, newer water-soluble pro-drugs, such as Minnelide, have been developed which have entered Phase II clinical trials (NCT03117920) [46]. In combination with R848 or similar TLR agonists, Minnelide may help induce TRAIL-mediated apoptosis of AML cells introducing another possible therapeutic strategy for AML.

R848 is also able to significantly upregulate the surface expression of CD40 on AML-patient pDCs.
Although pDCs take up less antigen than myeloid dendritic cells, they have been shown to induce potent $\mathrm{CD}^{+}$and $\mathrm{CD}^{+} \mathrm{T}$ cell responses when activated [47]. Activated pDCs express high levels of the co-stimulatory molecule CD86 (B7-2) which, when bound to CD28 on T-cells can induce $\mathrm{T}$ cell activation [48]. Another important interaction is between CD40 on pDCs and CD40L on T cells. Upon this interaction, IL-6 is released by pDCs, which then allows B cells to become antibody secreting plasma cells [48-52]. These R848-induced phenotypic changes help shift pDCs into an activated state, which can then potentially play a role in anti-tumor immunity both directly and indirectly.

Although we did not see clear patterns between mutational status/cytogenetic profile and the ability of the pDCs to produce IFN $\beta$, we did see that it was only the monocytic-lineage group (M5 classification by FAB) that showed this response. Further studies are required with larger sample numbers to determine more precisely which subtypes of AML are associated with IFN $\beta$-producing pDCs. For example, there is a possibility
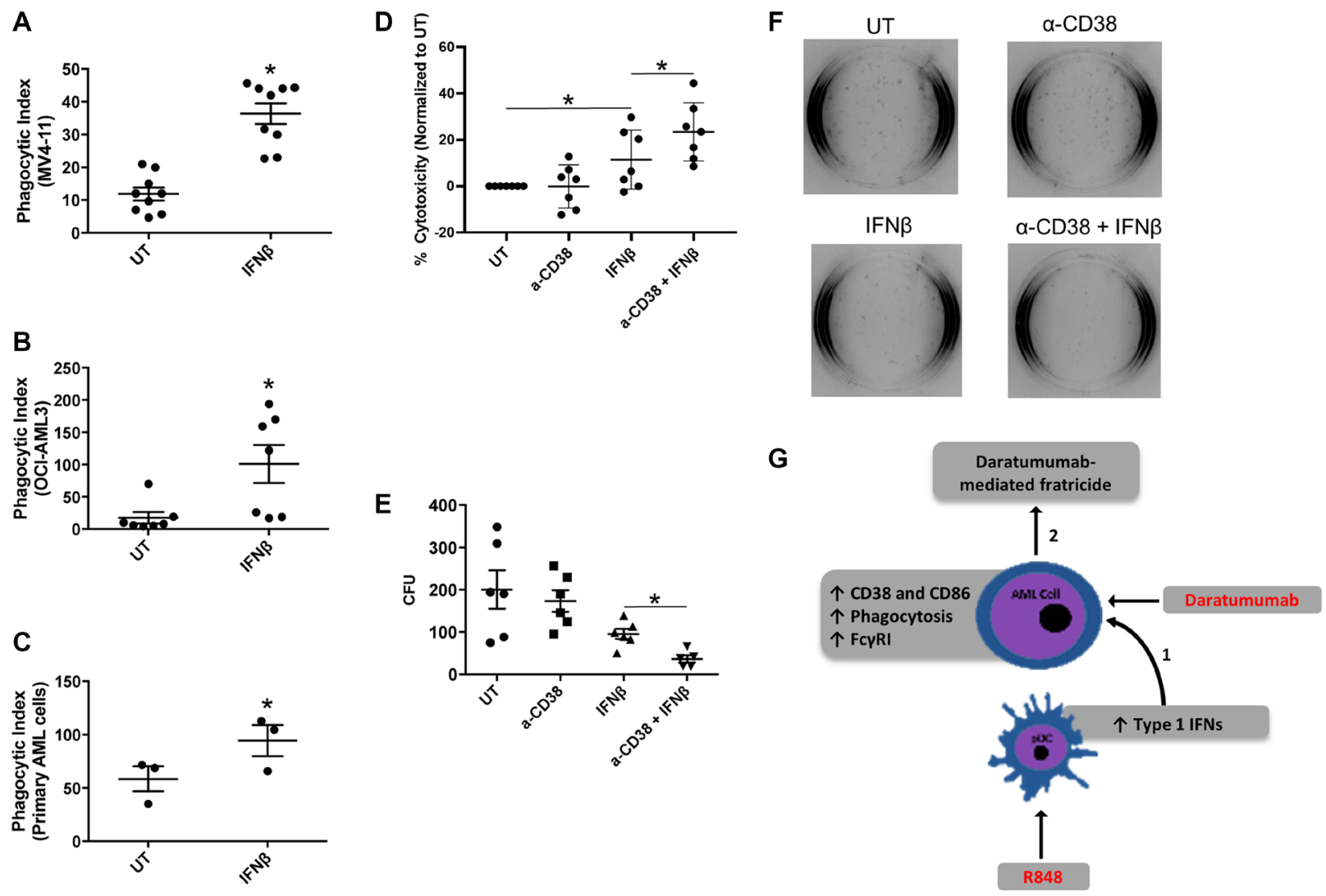

Figure 5: IFN $\beta$-induced AML-cell cytotoxicity is enhanced with anti-CD38 antibody daratumumab. (A-C) AML cell lines (MV-411, $n=9$ experiments and OCI-AML3, $n=7$ experiments) and primary AML apheresis samples $(n=3)$ were treated with or without $1000 \mathrm{U} / \mathrm{mL}$ IFN $\beta$ for $24 \mathrm{~h}$ and then incubated with opsonized sheep red blood cells. Phagocytosis was evaluated via microscopy in a blinded fashion. The phagocytic index represents the number of red blood cells ingested by 100 AML cells for each respective cell line. (D) OCI-AML3 cells ( $n=7$ experiments) were treated with or without anti-CD38 antibody ( $\alpha$-CD38, $20 \mu \mathrm{g} / \mathrm{mL}), \mathrm{IFN} \beta(500 \mathrm{U} / \mathrm{mL})$, or $\alpha$-CD38 + IFN $\beta$ for 48 hours. Cytotoxicity was then measured using a Lactate Dehydrogenase Assay. (E and F) MV4-11 cells $(n=6$ experiments) were treated with IFN $\beta(500 \mathrm{U} / \mathrm{mL})$ for 48 hours. Cells were then plated on methocult ${ }^{\mathrm{TM}}$-media-containing plates for 10 days, then colonies counted in a double-blinded fashion. (G) Current working model, as described in the text. ${ }^{*} p \leq 0.05$. 
that pDCs express different levels of molecules such as ILT7 [53], which recognizes Bone Marrow Stromal Antigen 2 (BST2) that is expressed on tumor cell lines and primary carcinomas $[54,55]$. Binding of ILT7 to BST2 may decrease Type I Interferon production [16]. Perhaps disrupting this ILT7/BST2 interaction could lead to enhanced IFN $\beta$ production in all AML subtypes.

Both the Type I IFNs, IFN $\alpha$ and IFN $\beta$ have been approved by the FDA for clinical use. IFN $\alpha$ has been used in the treatment of hairy cell leukemia, chronic myeloid leukemia, and has been studied in the context of AML [56-58]. In the setting of AML, IFN $\alpha$ therapy has been tested in multiple clinical trials in the context of inducing remission, salvage therapy, and post-remission therapy [59-61]. Type I IFNs have both direct and indirect effects on AML cells, which provides rationale for their use. Type I IFNs are able to induce both the canonical and non-canonical pathways, which can eventually induce apoptosis, inhibit cell proliferation, enhance AML cell immunogenicity, sensitize AML cells to differentiation, and reduce growth-promoting cytokine production by the AML cells [59]. In addition, Type I IFNs can increase the cross-priming ability of dendritic cells, and increase the cytotoxic abilities against leukemic cells by both DC $[59,62,63], \mathrm{T}[59,64]$ and NK cells [59]. Although IFN $\alpha$ has shown promising results in vitro, there have been problems that have led to modest results in in vivo and in clinical trials. Both IFN $\alpha$ and IFN $\beta$ have relatively short serum half-lives. Benjamin et al. showed that stable expression of IFN $\beta$ by virus-mediated gene transfer resulted in anti-leukemic effects when compared to bolus administration of IFN $\beta$. Although IFN $\beta$ levels were as low as $10 \mathrm{IU} / \mathrm{mL}$ in mice with stable expression of IFN $\beta$, AML tumor burden was significantly reduced when compared to control treated animals [65]. These data show the importance of generating longer lasting IFN preparations in order to achieve clinical efficacy. Both pegylated IFNs and albumin-IFN fusion proteins have been developed that help extend the serum half-life [66]. Pegylated forms of IFN $\alpha$ and IFN $\beta$ have been used in the setting of Hepatitis B and C (Pegylated Alfa-2a/Pegasys, Genentench Inc.) and in Multiple Sclerosis (Pegylated interferon beta-1a/ Plegridy, Biogen Canada) [67-69]. Here, we demonstrate another approach to overcome the limitation of the short half-life of exogenous IFN $\beta$ by inducing endogenous production of Type I IFN.

In summary, we report a novel mechanism of inducing the effector-like AML cell phenotype by reprogramming AML-patient $\mathrm{pDCs}$ to produce IFN $\beta$ through TLR stimulation. This can lead to upregulation of CD38 on AML cells and can enhance antibody-mediated fratricide of AML cells. These findings suggest that the use of either IFN $\beta$ or IFN $\beta$-inducing agents in combination with an anti-CD38 therapeutic antibody could likely offer a new therapeutic option for AML.

\section{MATERIALS AND METHODS}

\section{Antibodies and reagents}

Recombinant human IFN $\beta-1$ a (PBL, Piscataway, NJ, USA) was added to cell cultures at a concentration of $500 \mathrm{U} / \mathrm{mL}$. Daratumumab was used for LDH $(20 \mu \mathrm{g} /$ $\mathrm{ml}$ ) and colony forming assays. For flow cytometry, unconjugated mouse anti-human CD64 (clone 32.2) with an FITC goat anti-mouse secondary antibody (Invitrogen), anti-human CD38 conjugated to FITC (clone HIT2; BD Biosciences), anti-human CD86 conjugated to phycoerythrin (clone 2331 (FUN-1); BD Biosciences) were used to measure markers of activation on AML cells. For sorting, anti-human Lineage cocktail conjugated to APC (clone UCHT1, HCD14, 3G8, HIB19, 2H7, HCD56, Biolegend), anti-human HLA-DR conjugated to APC/Cy7 (clone L243, Biolegend), anti-human BDCA-2conjugated to FITC (clone 201A, Biolegend), and anti-human CD123 conjugated to $\mathrm{PE} / \mathrm{Cy} 7$ (clone $6 \mathrm{H} 6$, Biolegend) were used. For the identification and measurement of activation status of plasmacytoid dendritic cells, antihuman Lineage cocktail conjugated to BV510 (clone OKT3, M5E2, 3G8, HIB19, 2H7, HCD56, Biolegend), anti-human CD123 conjugated to BV650 (clone 6H6, Biolegend), anti-human HLA-DR conjugated to APC/Cy7 (clone L243, Biolegend), anti-human BDCA-2 conjugated to $\mathrm{PE} / \mathrm{Cy} 7$ (clone 201A, Biolegend), anti-human CD80 conjugated to BV421 (clone 2D10, Biolegend), antihuman CD62L conjugated to PerCP (clone DREG-56, Biolegend), anti-human CD86 conjugated to APC (clone IT2.2, Biolegend), and anti-human CD40 conjugated to PE (clone 5C3, Biolegend) were used. Samples were analyzed using an LSRII flow cytometer (BD Bioscience) and FlowJo software (FLOWJO, LLC, Ashland, OR, USA). The JAK1/2 inhibitor, ruxolitinib (used at $50 \mathrm{nM}$ ), was purchased from Selleck Chemicals (Houston, TX, USA). The MEK inhibitor, PD0325901 (used at $0.5 \mu \mathrm{M}$ ) was purchased from Selleck Chemicals (Houston, TX, USA). The p38 MAPK inhibitor, SB202190 (used at 1 $\mu \mathrm{M}$ ) was purchased from Selleck Chemicals (Houston, TX, USA).

\section{Cell culture}

The AML cell lines used in this study (MV4-11 and OCI-AML3) were purchased from ATCC and cultured according to ATCC recommendations. Cells were maintained below $1 \times 10^{6}$ cells $/ \mathrm{mL}$ in RPMI 1640 media (Gibco, Grand Island, NY, USA) supplemented with $10 \%$ heat-inactivated fetal bovine serum (FBS; Hyclone Laboratories, Grand Island, NY, USA), 2 mM L-glutamine (Invitrogen, Grand Island, NY, USA), and penicillin/ streptomycin $\left(56 \mathrm{U} / \mathrm{mL} / 56 \mu \mathrm{g} / \mathrm{mL}\right.$; Invitrogen) at $37^{\circ} \mathrm{C}$ in an atmosphere of $5 \% \mathrm{CO}_{2}$. 


\section{Primary cells}

Primary cell handling was done as described previously [3]. White blood cells apheresed from AML patients were obtained after written informed consent in accordance with the Declaration of Helsinki under a protocol approved by the institutional review board of The Ohio State University. Cells were stored in liquid nitrogen in $20 \% \mathrm{FBS}$ and $10 \%$ DMSO until needed for experiments. At the time of the experiment, cells were thawed at $37^{\circ} \mathrm{C}$ and incubated in RPMI 1640 media (Gibco) supplemented with $20 \%$ FBS, $2 \mathrm{mM} \mathrm{L-glutamine} \mathrm{(Invitrogen)} \mathrm{and}$ penicillin/streptomycin ( $56 \mathrm{U} / \mathrm{mL} / 56 \mu \mathrm{g} / \mathrm{mL}$; Invitrogen) at $37^{\circ} \mathrm{C}$ in an atmosphere of $5 \% \mathrm{CO}_{2}$ for 1 hour. Cells were then centrifuged and incubated at $3 \times 10^{6} / \mathrm{mL}$ in RPMI 1640 media (Gibco) supplemented with 20\% FBS, 2 mM L-glutamine (Invitrogen) and penicillin/streptomycin (56 $\mathrm{U} / \mathrm{mL} / 56 \mu \mathrm{g} / \mathrm{mL}$; Invitrogen) and were either left untreated or treated with Interferon-beta (IFN- $\beta$ ) and incubated for 24 hours at $37^{\circ} \mathrm{C}$. The next day, cells were counted using Trypan blue exclusion and used for assays.

\section{Western blotting}

Anti-pSTAT1, Anti-p-MAPKAPK-2, Anti-pERK, Anti-MAPKAPK-2, and anti-IRF9 for Western blotting were purchased from Cell Signaling Technology (Danvers, MA, USA). Anti-Calreticulin antibody was purchased from Enzo Life Sciences (Farmingdale, NY, USA). Anti-GAPDH antibody was purchased from Santa Cruz Biotechnology (Dallas, TX, USA). Western blotting was done as described previously [70]. Cells were lysed in TN1 buffer (50 mM Tris ( $\mathrm{pH} 8.0$ ), $10 \mathrm{mM}$ EDTA, 10 $\mathrm{mM} \mathrm{Na} \mathrm{P}_{2} \mathrm{O}_{7}, 10 \mathrm{mM} \mathrm{NaF}, 1 \%$ Triton X-100, $125 \mathrm{mM}$ $\mathrm{NaCl}, 10 \mathrm{mM} \mathrm{Na}_{3} \mathrm{VO}_{4}$, and $10 \mu \mathrm{g} / \mathrm{ml}$ each aprotinin and leupeptin). Protein lysates were boiled in Laemmli sample buffer, separated by SDS-PAGE, transferred to nitrocellulose membranes, probed with the antibody of interest, and then developed by Pierce ECL 2 Western blotting substrate (Thermo Scientific, Rockford, IL, USA) or SuperSignal West Femto maximum sensitivity substrate (Thermo Scientific). Densitometry was performed using ImageJ software (National Institutes of Health, Bethesda, MD, USA), and ratios between the indicated probes and their respective anti-actin reprobes were calculated.

\section{Colony forming assay}

MV4-11 cells were treated with or without IFN- $\beta$ $(500 \mathrm{U} / \mathrm{mL})$ in the presence or absence of daratumumab (20 $\mu \mathrm{g} / \mathrm{mL}$, supplied from commercial sources, The Ohio State University, Columbus, OH, USA) for 24 hours then plated in duplicates in Methocult ${ }^{\mathrm{TM}} \mathrm{H} 4100$ methylcellulose medium (StemCell Technologies) on cell culture plates for 10 days. After 10 days, colonies were scored in a double-blind fashion.

\section{Lactate dehydrogenase assay}

OCI-AML 3 cells were plated at $5 \times 10^{5}$ cells/ $\mathrm{mL}$ and treated with $500 \mathrm{U}$ IFN $\beta$ and/or $20 \mu \mathrm{g} / \mathrm{mL}$ daratumumab. After 48 hours, supernatants were removed and used for a CytoTox96 ${ }^{\circledR}$ Non-Radio Cytotoxicity Assay (Promega, Madison, WI, USA) according to manufacturer's instruction. Percent cytotoxicity was defined as [Experimental LDH release $\mathrm{OD}_{490} /$ Maximum $\mathrm{LDH}$ release $\left.\mathrm{OD}_{490}\right] \times 100$.

\section{Phagocytosis}

Phagocytosis assays were performed as described previously with minor adaptations for the experimental requirements of this study [71]. Briefly, sheep red blood cells (SRBCs; Colorado Serum Company, Denver, CO, USA) were labeled with PKH26 fluorescent cell membrane dye (Sigma) and then opsonized with anti-SRBC antibody (Sigma). SRBCs were added to the respective AML cell lines (treated with IFN- $\beta$ for 24 hours) or primary AML apheresis samples (treated with IFN- $\beta$ for $24 \mathrm{~h}$ ), gently pelleted by slow centrifugation, and then incubated at $37^{\circ} \mathrm{C}$ for 1 hour. Non-phagocytosed SRBCs were lysed with red blood cell lysis buffer (eBioscience, San Diego, CA, USA) at room temperature for $10 \mathrm{~min}$ and washed with PBS before fixation with $4 \%$ paraformaldehyde. The SRBCs ingested by the AML cells were counted in a blinded fashion using fluorescence microscopy, with three separate such counts per condition. For each set of counts, 100 AML cells per condition were examined. The phagocytic index is defined as the total number of SRBCs ingested by 100 AML cells.

\section{Real-time PCR}

Total RNA was isolated using the Norgen Biotek Total RNA Purification Kit (Norgen Biotek Corp., Ontario, Canada) according to manufacturer's instructions. RNA was reverse transcribed and subjected to quantitative real-time PCR using Power SYBR Green Master Mix (Applied Biosystems, Grand Island, NY, USA) as previously described [3]. The following primers were used: GAPDH (forward primer, 5'-ATT CCC TGG ATT GTG AAA TAG TC-3'; reverse primer, 5'-ATTAAAGTCACCGCCTTCTGTAG-3'), CD38 (forward primer, 5'-GCTCAATGGATCCCGCAGT-3'; reverse primer, 5'-TCCTGGCARAAGTCTCTGG-3'), and TRAIL (forward primer 5'-AAG GCT CTG GGC CGC AAA ATA AAC-3'and reverse primer 5'-GCC AAC TAA AAA GGC CCC GAA AAA-3'). GAPDH was used for normalization of the genes of interest. Data were presented as mean relative copy number for at least three separate experiments using relative copy number $=2^{-\Delta C t} \times 100$ [72], where $\Delta C t$ is the $C t_{\text {target }}-C t_{\mathrm{GAPDH}}$. 


\section{Statistics}

For experiments that involved placing the cells of each donor across multiple conditions, mixed-effect modeling was done. For experiments with only two groups involved, unpaired two-tailed (Figure 1B) or paired two-tailed (all others) Student's $t$-tests were used to test for statistically significant differences. Analyses were performed using SAS (SAS Inc., Cary, NC, USA) and Microsoft Excel (Microsoft, Redmond, WA, USA).

\section{Author contributions}

$\mathrm{KF}, \mathrm{PM}, \mathrm{CBC}, \mathrm{NJB}, \mathrm{RS}, \mathrm{GMR}, \mathrm{HI}$ and $\mathrm{BS}$ performed experiments; XM assisted with experimental design and performed statistical analyses; BM, ST and JPB oversaw the project, interpreted data and designed experiments.

\section{CONFLICTS OF INTEREST}

All authors declare that there are no conflicts of interest regarding this manuscript.

\section{FUNDING}

This work was funded by NIH R01CA203584. GMR was funded by a Pelotonia predoctoral fellowship, The Ohio State University Comprehensive Cancer Center. Research reported in this publication was supported by The Ohio State University Comprehensive Cancer Center and the National Institutes of Health under grant number P30 CA016058. We are grateful to the patients (and healthy volunteers) who provided tissue samples for these studies to the OSU Comprehensive Cancer Center Leukemia Tissue Bank Shared Resource (supported by NIH NCI P30 CA016058).

\section{REFERENCES}

1. Isidori A, Salvestrini V, Ciciarello M, Loscocco F, Visani G, Parisi S, Lecciso M, Ocadlikova D, Rossi L, Gabucci E, Clissa C, Curti A. The role of the immunosuppressive microenvironment in acute myeloid leukemia development and treatment. Expert Rev Hematol. 2014; 7:807-18. https://doi.org/10.1586/17474086.2014.958464. [PubMed]

2. Cuesta-Mateos C, Alcaraz-Serna A, Somovilla-Crespo B, Muñoz-Calleja C. Monoclonal Antibody Therapies for Hematological Malignancies: Not Just Lineage-Specific Targets. Front Immunol. 2018; 8:1936. https://doi. org/10.3389/fimmu.2017.01936. [PubMed]

3. Fatehchand K, McMichael EL, Reader BF, Fang H, Santhanam R, Gautam S, Elavazhagan S, Mehta P, Buteyn NJ, Merchand-Reyes G, Vasu S, Mo X, Benson DM Jr, et al. Interferon- $\gamma$ Promotes Antibody-mediated Fratricide of Acute Myeloid Leukemia Cells. J Biol Chem. 2016; 291:25656-66. [ubMed]

4. Stone RM, Spriggs DR, Arthur KA, Mayer RJ, Griffin J, Kufe DW. Recombinant human gamma interferon administered by continuous intravenous infusion in acute myelogenous leukemia and myelodysplastic syndromes. Am J Clin Oncol. 1993; 16:159-63. https://doi. org/10.1097/00000421-199304000-00017. [PubMed]

5. Palva IP, Almqvist A, Elonen E, Hänninen A, Jouppila J, Järventie G, Koivunen E, Kätkä K, Lahtinen R, Oivanen T, Pelliniemi TT, Rajamäki A, Remes K, et al. Value of maintenance therapy with chemotherapy or interferon during remission of acute myeloid leukaemia. Eur J Haematol. 1991; 47:229-33. https://doi. org/10.1111/j.1600-0609.1991.tb01560.x. [PubMed]

6. Goldstone AH, Burnett AK, Wheatley K, Smith AG, Hutchinson RM, Clark RE, and Medical Research Council Adult Leukemia Working Party. Attempts to improve treatment outcomes in acute myeloid leukemia (AML) in older patients: the results of the United Kingdom Medical Research Council AML11 trial. Blood. 2001; 98:1302-11. https://doi.org/10.1182/blood.v98.5.1302. [PubMed]

7. Lin FC, Young HA. Interferons: Success in anti-viral immunotherapy. Cytokine Growth Factor Rev. 2014; 25:369-76. https://doi.org/10.1016/j.cytogfr.2014.07.015. [PubMed]

8. Schreiber G. The molecular basis for differential type I interferon signaling. J Biol Chem. 2017; 292:7285-94. https://doi.org/10.1074/jbc.R116.774562. [PubMed]

9. Swiecki M, Colonna M. The multifaceted biology of plasmacytoid dendritic cells. Nat Rev Immunol. 2015; 15:471-85. https://doi.org/10.1038/nri3865. [PubMed]

10. Li S, Wu J, Zhu S, Liu YJ, Chen J. Disease-Associated Plasmacytoid Dendritic Cells. Front Immunol. 2017; 8:1268. https://doi.org/10.3389/fimmu.2017.01268. [PubMed]

11. Swiecki M, Colonna M. Unraveling the functions of plasmacytoid dendritic cells during viral infections, autoimmunity, and tolerance. Immunol Rev. 2010; 234:142-62. https://doi.org/10.1111/j.0105-2896.2009.00881.x. [PubMed]

12. Liu YJ. IPC: professional type 1 interferon-producing cells and plasmacytoid dendritic cell precursors. Annu Rev Immunol. 2005; 23:275-306. https://doi.org/10.1146/ annurev.immunol.23.021704.115633. [PubMed]

13. Gilliet M, Cao W, Liu YJ. Plasmacytoid dendritic cells: sensing nucleic acids in viral infection and autoimmune diseases. Nat Rev Immunol. 2008; 8:594-606. https://doi. org/10.1038/nri2358. [PubMed]

14. Ito T, Wang YH, Liu YJ. Plasmacytoid dendritic cell precursors/type I interferon-producing cells sense viral infection by Toll-like receptor (TLR) 7 and TLR9. Springer Semin Immunopathol. 2005; 26:221-29. https://doi. org/10.1007/s00281-004-0180-4. [PubMed]

15. Decalf J, Fernandes S, Longman R, Ahloulay M, Audat F, Lefrerre F, Rice CM, Pol S, Albert ML. Plasmacytoid 
dendritic cells initiate a complex chemokine and cytokine network and are a viable drug target in chronic $\mathrm{HCV}$ patients. J Exp Med. 2007; 204:2423-37. https://doi. org/10.1084/jem.20070814. [ [PubMed]

16. Vermi W, Soncini M, Melocchi L, Sozzani S, Facchetti F. Plasmacytoid dendritic cells and cancer. J Leukoc Biol. 2011; 90:681-90. https://doi.org/10.1189/jlb.0411190. [PubMed]

17. Rickmann M, Krauter J, Stamer K, Heuser M, Salguero G, Mischak-Weissinger E, Ganser A, Stripecke R. Elevated frequencies of leukemic myeloid and plasmacytoid dendritic cells in acute myeloid leukemia with the FLT3 internal tandem duplication. Ann Hematol. 2011; 90:104758. https://doi.org/10.1007/s00277-011-1231-2. [PubMed]

18. Akira S, Hemmi H. Recognition of pathogen-associated molecular patterns by TLR family. Immunol Lett. 2003; 85:85-95. https://doi.org/10.1016/s0165-2478(02)002286. [PubMed]

19. Martinson JA, Roman-Gonzalez A, Tenorio AR, Montoya CJ, Gichinga CN, Rugeles MT, Tomai M, Krieg AM, Ghanekar S, Baum LL, Landay AL. Dendritic cells from HIV-1 infected individuals are less responsive to toll-like receptor (TLR) ligands. Cell Immunol. 2007; 250:75-84. https://doi.org/10.1016/j.cellimm.2008.01.007. [PubMed]

20. Gibson SJ, Lindh JM, Riter TR, Gleason RM, Rogers LM, Fuller AE, Oesterich JL, Gorden KB, Qiu X, McKane SW, Noelle RJ, Miller RL, Kedl RM, et al. Plasmacytoid dendritic cells produce cytokines and mature in response to the TLR7 agonists, imiquimod and resiquimod. Cell Immunol. 2002; 218:74-86. https://doi.org/10.1016/s00088749(02)00517-8. [PubMed]

21. Cella M, Salio M, Sakakibara Y, Langen H, Julkunen I, Lanzavecchia A. Maturation, activation, and protection of dendritic cells induced by double-stranded RNA. J Exp Med. 1999; 189:821-29. https://doi.org/10.1084/ jem.189.5.821. [PubMed]

22. Inglefield JR, Dumitru CD, Alkan SS, Gibson SJ, Lipson KE, Tomai MA, Larson CJ, Vasilakos JP. TLR7 agonist $852 \mathrm{~A}$ inhibition of tumor cell proliferation is dependent on plasmacytoid dendritic cells and type I IFN. J Interferon Cytokine Res. 2008; 28:253-63. https://doi.org/10.1089/ jir.2007.0097. [PubMed]

23. Chaperot L, Blum A, Manches O, Lui G, Angel J, Molens JP, Plumas J. Virus or TLR agonists induce TRAILmediated cytotoxic activity of plasmacytoid dendritic cells. J Immunol. 2006; 176:248-55. https://doi.org/10.4049/ jimmunol.176.1.248. [PubMed]

24. Riccioni R, Pasquini L, Mariani G, Saulle E, Rossini A, Diverio D, Pelosi E, Vitale A, Chierichini A, Cedrone M, Foà R, Lo Coco F, Peschle C, Testa U. TRAIL decoy receptors mediate resistance of acute myeloid leukemia cells to TRAIL. Haematologica. 2005; 90:612-24. [PubMed]

25. Carter BZ, Mak DH, Schober WD, Dietrich MF, Pinilla C, Vassilev LT, Reed JC, Andreeff M. Triptolide sensitizes AML cells to TRAIL-induced apoptosis via decrease of XIAP and p53-mediated increase of DR5. Blood. 2008; 111:3742-50. https://doi.org/10.1182/ blood-2007-05-091504. [PubMed]

26. Bansal H, Seifert T, Bachier C, Rao M, Tomlinson G, Iyer SP, Bansal S. The transcription factor Wilms tumor 1 confers resistance in myeloid leukemia cells against the proapoptotic therapeutic agent TRAIL (tumor necrosis factor $\alpha$-related apoptosis-inducing ligand) by regulating the antiapoptotic protein Bcl-xL. J Biol Chem. 2012; 287:32875-80. https://doi.org/10.1074/jbc.C112.366559. [PubMed]

27. Platanias LC. Mechanisms of type-I- and type-II-interferonmediated signalling. Nat Rev Immunol. 2005; 5:375-86. https://doi.org/10.1038/nri1604. [PubMed]

28. Chen K, Liu J, Cao X. Regulation of type I interferon signaling in immunity and inflammation: A comprehensive review. J Autoimmun. 2017; 83:1-11. https://doi. org/10.1016/j.jaut.2017.03.008. [PubMed]

29. David M, Petricoin E 3rd, Benjamin C, Pine R, Weber MJ, Larner AC. Requirement for MAP kinase (ERK2) activity in interferon alpha- and interferon beta-stimulated gene expression through STAT proteins. Science. 1995; 269:172123. https://doi.org/10.1126/science.7569900. [PubMed]

30. Lunghi P, Tabilio A, Dall'Aglio PP, Ridolo E, Carlo-Stella C, Pelicci PG, Bonati A. Downmodulation of ERK activity inhibits the proliferation and induces the apoptosis of primary acute myelogenous leukemia blasts. Leukemia. 2003; 17:1783-93. https://doi.org/10.1038/sj.leu.2403032. [PubMed]

31. Ricciardi MR, McQueen T, Chism D, Milella M, Estey E, Kaldjian E, Sebolt-Leopold J, Konopleva M, Andreeff M. Quantitative single cell determination of ERK phosphorylation and regulation in relapsed and refractory primary acute myeloid leukemia. Leukemia. 2005; 19:1543-49. https://doi.org/10.1038/sj.leu.2403859. [PubMed]

32. Hayun M, Zaatra M, Itzkovich C, Sahar D, Rosenberg D, Filatova M, Ringelstein-Harlev S, Baris H, MoustafaHawash N, Louria-Hayon I, Ofran Y. ERK Activity in Immature Leukemic Cells Drives Clonal Selection during Induction Therapy for Acute Myeloid Leukemia. Sci Rep. 2020; 10:8349. https://doi.org/10.1038/s41598-020-650616. [PubMed]

33. Quintás-Cardama A, Vaddi K, Liu P, Manshouri T, Li J, Scherle PA, Caulder E, Wen X, Li Y, Waeltz P, Rupar M, Burn T, Lo Y, et al. Preclinical characterization of the selective JAK1/2 inhibitor INCB018424: therapeutic implications for the treatment of myeloproliferative neoplasms. Blood. 2010; 115:3109-17. https://doi. org/10.1182/blood-2009-04-214957. [PubMed]

34. Uddin S, Sweet M, Colamonici OR, Krolewski JJ, Platanias LC. The vav proto-oncogene product (p95vav) interacts with the Tyk-2 protein tyrosine kinase. FEBS Lett. 1997; 403:31-34. https://doi.org/10.1016/s0014-5793(97)000239. [PubMed] 
35. Katsoulidis E, Li Y, Mears H, Platanias LC. The p38 mitogen-activated protein kinase pathway in interferon signal transduction. J Interferon Cytokine Res. 2005; 25:749-56. https://doi.org/10.1089/jir.2005.25.749. [PubMed]

36. Uddin S, Majchrzak B, Woodson J, Arunkumar P, Alsayed Y, Pine R, Young PR, Fish EN, Platanias LC. Activation of the p38 mitogen-activated protein kinase by type I interferons. J Biol Chem. 1999; 274:30127-31. https://doi. org/10.1074/jbc.274.42.30127. [PubMed]

37. Siegal FP, Kadowaki N, Shodell M, Fitzgerald-Bocarsly PA, Shah K, Ho S, Antonenko S, Liu YJ. The nature of the principal type 1 interferon-producing cells in human blood. Science. 1999; 284:1835-37. https://doi.org/10.1126/ science.284.5421.1835. [PubMed]

38. Asselin-Paturel C, Trinchieri G. Production of type I interferons: plasmacytoid dendritic cells and beyond. J Exp Med. 2005; 202:461-65. https://doi.org/10.1084/ jem.20051395. [PubMed]

39. Colonna M, Trinchieri G, Liu YJ. Plasmacytoid dendritic cells in immunity. Nat Immunol. 2004; 5:1219-26. https:// doi.org/10.1038/ni1141. [PubMed]

40. Lee GH, Askari A, Malietzis G, Bernardo D, Clark SK, Knight SC, Al-Hassi HO. The role of CD40 expression in dendritic cells in cancer biology; a systematic review. Curr Cancer Drug Targets. 2014; 14:610-20. https://doi.org/10.2 174/1568009614666140828103253. [PubMed]

41. Ivetic A, Hoskins Green HL, Hart SJ. L-selectin: A Major Regulator of Leukocyte Adhesion, Migration and Signaling. Front Immunol. 2019; 10:1068. https://doi.org/10.3389/ fimmu.2019.01068. [PubMed]

42. Vanbervliet B, Bendriss-Vermare N, Massacrier C, Homey $\mathrm{B}$, de Bouteiller $\mathrm{O}$, Brière F, Trinchieri G, Caux C. The inducible CXCR3 ligands control plasmacytoid dendritic cell responsiveness to the constitutive chemokine stromal cell-derived factor 1 (SDF-1)/CXCL12. J Exp Med. 2003; 198:823-30. https://doi.org/10.1084/jem.20020437. [PubMed]

43. Fiore F, Von Bergwelt-Baildon MS, Drebber U, Beyer M, Popov A, Manzke O, Wickenhauser C, Baldus SE, Schultze JL. Dendritic cells are significantly reduced in non-Hodgkin's lymphoma and express less CCR7 and CD62L. Leuk Lymphoma. 2006; 47:613-22. https://doi. org/10.1080/10428190500360971. [PubMed]

44. Stary G, Bangert C, Tauber M, Strohal R, Kopp T, Stingl G. Tumoricidal activity of TLR7/8-activated inflammatory dendritic cells. J Exp Med. 2007; 204:1441-51. https://doi. org/10.1084/jem.20070021. [PubMed]

45. Liu Q. Triptolide and its expanding multiple pharmacological functions. Int Immunopharmacol. 2011; 11:377-83. https://doi.org/10.1016/j.intimp.2011.01.012. [PubMed]

46. Banerjee S, Saluja A. Minnelide, a novel drug for pancreatic and liver cancer. Pancreatology. 2015 (4 Suppl); 15:S39-43. https://doi.org/10.1016/j.pan.2015.05.472. [PubMed]
47. Tel J, Schreibelt G, Sittig SP, Mathan TS, Buschow SI, Cruz LJ, Lambeck AJ, Figdor CG, de Vries IJ. Human plasmacytoid dendritic cells efficiently cross-present exogenous Ags to CD8+ T cells despite lower Ag uptake than myeloid dendritic cell subsets. Blood. 2013; 121:459-67. https://doi.org/10.1182/blood-2012-06-435644. [PubMed]

48. Mathan TS, Figdor CG, Buschow SI. Human plasmacytoid dendritic cells: from molecules to intercellular communication network. Front Immunol. 2013; 4:372. https://doi.org/10.3389/fimmu.2013.00372. [PubMed]

49. Fonteneau JF, Gilliet M, Larsson M, Dasilva I, Münz C, Liu YJ, Bhardwaj N. Activation of influenza virus-specific CD4+ and CD8+ T cells: a new role for plasmacytoid dendritic cells in adaptive immunity. Blood. 2003; 101:3520-26. https://doi.org/10.1182/blood-2002-10-3063. [PubMed]

50. Jego G, Palucka AK, Blanck JP, Chalouni C, Pascual V, Banchereau J. Plasmacytoid dendritic cells induce plasma cell differentiation through type I interferon and interleukin 6. Immunity. 2003; 19:225-34. https://doi.org/10.1016/ s1074-7613(03)00208-5. [PubMed]

51. Donhauser N, Pritschet K, Helm M, Harrer T, Schuster P, Ries M, Bischof G, Vollmer J, Smola S, Schmidt B, and German Competence Network HIV/AIDS. Chronic immune activation in HIV-1 infection contributes to reduced interferon alpha production via enhanced CD40:CD40 ligand interaction. PLoS One. 2012; 7:e33925. https://doi. org/10.1371/journal.pone.0033925. [PubMed]

52. García-Marquez M, Shimabukuro-Vornhagen A, von Bergwelt-Baildon M. Complex interactions between B cells and dendritic cells. Blood. 2013; 121:2367-68. https://doi. org/10.1182/blood-2012-12-468017. [PubMed]

53. Cao W, Rosen DB, Ito T, Bover L, Bao M, Watanabe G, Yao Z, Zhang L, Lanier LL, Liu YJ. Plasmacytoid dendritic cell-specific receptor ILT7-Fc epsilonRI gamma inhibits Toll-like receptor-induced interferon production. J Exp Med. 2006; 203:1399-405. https://doi.org/10.1084/ jem.20052454. [PubMed]

54. Cai D, Cao J, Li Z, Zheng X, Yao Y, Li W, Yuan Z. Upregulation of bone marrow stromal protein 2 (BST2) in breast cancer with bone metastasis. BMC Cancer. 2009; 9:102. https://doi.org/10.1186/1471-2407-9-102. [PubMed]

55. Wang W, Nishioka Y, Ozaki S, Jalili A, Abe S, Kakiuchi $\mathrm{S}$, Kishuku M, Minakuchi K, Matsumoto T, Sone S. HM1.24 (CD317) is a novel target against lung cancer for immunotherapy using anti-HM1.24 antibody. Cancer Immunol Immunother. 2009; 58:967-76. https://doi. org/10.1007/s00262-008-0612-4. [PubMed]

56. Damasio EE, Clavio M, Masoudi B, Isaza A, Spriano M, Rossi E, Casciaro S, Cerri R, Risso M, Nati S, Siccardi M, Truini M, Gobbi M. Alpha-interferon as induction and maintenance therapy in hairy cell leukemia: a long-term follow-up analysis. Eur J Haematol. 2000; 64:47-52. https:// doi.org/10.1034/j.1600-0609.2000.90014.x. [PubMed]

57. Kujawski LA, Talpaz M. The role of interferon-alpha in the treatment of chronic myeloid leukemia. Cytokine Growth 
Factor Rev. 2007; 18:459-71. https://doi.org/10.1016/j. cytogfr.2007.06.015. [PubMed]

58. Kiladjian JJ, Chomienne C, Fenaux P. Interferon-alpha therapy in bcr-abl-negative myeloproliferative neoplasms. Leukemia. 2008; 22:1990-98. https://doi.org/10.1038/ leu.2008.280. [PubMed]

59. Anguille S, Lion E, Willemen Y, Van Tendeloo VF, Berneman ZN, Smits EL. Interferon- $\alpha$ in acute myeloid leukemia: an old drug revisited. Leukemia. 2011; 25:739-48. https://doi.org/10.1038/leu.2010.324. [PubMed]

60. Berneman ZN, Anguille S, Van Marck V, Schroyens WA, Van Tendeloo VF. Induction of complete remission of acute myeloid leukaemia by pegylated interferon-alpha$2 \mathrm{a}$ in a patient with transformed primary myelofibrosis. Br J Haematol. 2010; 149:152-55. https://doi.org/10.1111/ j.1365-2141.2009.08029.x. [PubMed]

61. Dagorne A, Douet-Guilbert N, Quintin-Roue I, Guillerm G, Couturier MA, Berthou C, Ianotto JC. Pegylated interferon $\alpha 2 \mathrm{a}$ induces complete remission of acute myeloid leukemia in a postessential thrombocythemia myelofibrosis permitting allogenic stem cell transplantation. Ann Hematol. 2013; 92:407-09. https://doi.org/10.1007/s00277012-1560-9. [PubMed]

62. Ferrantini M, Capone I, Belardelli F. Interferon-alpha and cancer: mechanisms of action and new perspectives of clinical use. Biochimie. 2007; 89:884-93. https://doi. org/10.1016/i.biochi.2007.04.006. [PubMed]

63. Le Bon A, Tough DF. Type I interferon as a stimulus for cross-priming. Cytokine Growth Factor Rev. 2008; 19:33-40. https://doi.org/10.1016/j.cytogfr.2007.10.007. [PubMed]

64. Watanabe N, Narita M, Yokoyama A, Sekiguchi A, Saito A, Tochiki N, Furukawa T, Toba K, Aizawa Y, Takahashi M. Type I IFN-mediated enhancement of anti-leukemic cytotoxicity of gammadelta $\mathrm{T}$ cells expanded from peripheral blood cells by stimulation with zoledronate. Cytotherapy. 2006; 8:118-29. https://doi.org/10.1080/14653240600620200. [PubMed]

65. Benjamin R, Khwaja A, Singh N, McIntosh J, Meager A, Wadhwa M, Streck C, Ng C, Davidoff AM, Nathwani AC. Continuous delivery of human type I interferons (alpha/beta) has significant activity against acute myeloid leukemia cells in vitro and in a xenograft model. Blood. 2007; 109:1244- 47. https://doi.org/10.1182/blood-2006-02-002915. [PubMed]
66. Luxon BA, Grace M, Brassard D, Bordens R. Pegylated interferons for the treatment of chronic hepatitis $\mathrm{C}$ infection. Clin Ther. 2002; 24:1363-83. https://doi.org/10.1016/ s0149-2918(02)80042-x. [PubMed]

67. Marcellin P, Lau GK, Bonino F, Farci P, Hadziyannis S, Jin R, Lu ZM, Piratvisuth T, Germanidis G, Yurdaydin C, Diago M, Gurel S, Lai MY, et al, and Peginterferon Alfa2a HBeAg-Negative Chronic Hepatitis B Study Group. Peginterferon alfa-2a alone, lamivudine alone, and the two in combination in patients with $\mathrm{HBeAg}$-negative chronic hepatitis B. N Engl J Med. 2004; 351:1206-17. https://doi. org/10.1056/NEJMoa040431. [PubMed]

68. Fried MW, Shiffman ML, Reddy KR, Smith C, Marinos G, Gonçales FL Jr, Häussinger D, Diago M, Carosi G, Dhumeaux D, Craxi A, Lin A, Hoffman J, Yu J. Peginterferon alfa-2a plus ribavirin for chronic hepatitis C virus infection. N Engl J Med. 2002; 347:975-82. https:// doi.org/10.1056/NEJMoa020047. [ [PubMed]

69. Kieseier BC, Calabresi PA. PEGylation of interferon- $\beta-1 \mathrm{a}$ : a promising strategy in multiple sclerosis. CNS Drugs. 2012; 26:205-14. https://doi.org/10.2165/11596970-00000000000000. [PubMed]

70. Fatehchand K, Ren L, Elavazhagan S, Fang H, Mo X, Vasilakos JP, Dietsch GN, Hershberg RM, Tridandapani S, Butchar JP. Toll-like Receptor 4 Ligands Down-regulate Fc $\gamma$ Receptor IIb (Fc $\gamma$ RIIb) via MARCH3 Protein-mediated Ubiquitination. J Biol Chem. 2016; 291:3895-904. https:// doi.org/10.1074/jbc.M115.701151. [PubMed]

71. Joshi T, Ganesan LP, Cao X, Tridandapani S. Molecular analysis of expression and function of hFcgammaRIIbl and b2 isoforms in myeloid cells. Mol Immunol. 2006; 43:839-50. https://doi.org/10.1016/j.molimm.2005.06.037. [PubMed]

72. Gavrilin MA, Bouakl IJ, Knatz NL, Duncan MD, Hall MW, Gunn JS, Wewers MD. Internalization and phagosome escape required for Francisella to induce human monocyte IL-1beta processing and release. Proc Natl Acad Sci U S A. 2006; 103:141-46. https://doi.org/10.1073/pnas.0504271103. [PubMed] 